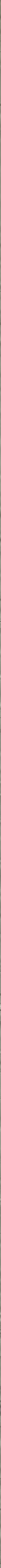




\section{HARVARD UNIVERSITY.}

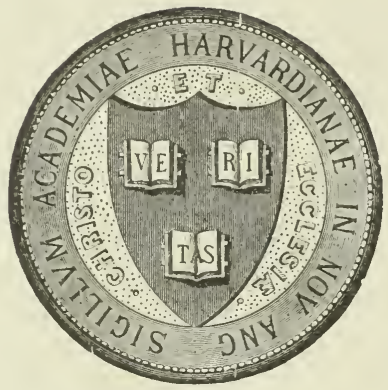

\section{LIBRARY}

OF THE

MUSEUM OF COMPARATIVE ZOÖLOGY.

$$
\begin{aligned}
& 34,665 \\
& \text { Gxchange }
\end{aligned}
$$

Novenber 3, 1909. 
34,665

\section{MOUSE PLAGUES, THEIR CONTROL AND PREVENTION.}

By

STANLEY E. PIPER,

Assistant, Biological Survey.

[Reprint from Yearbook of Department of Agriculture for 1908.] 


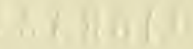

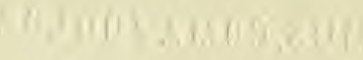

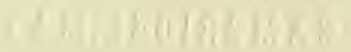




\section{CONTENTS.}

\begin{tabular}{|c|c|}
\hline 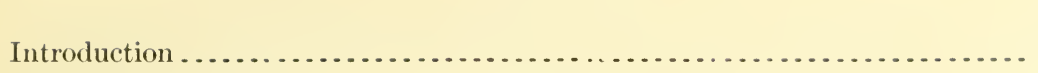 & $\begin{array}{r}\text { Page. } \\
301\end{array}$ \\
\hline 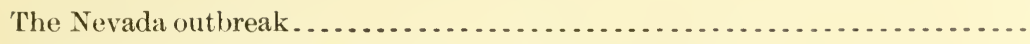 & 302 \\
\hline lit. f $^{2}$. & 302 \\
\hline ature and duration of mouse plagues........... & 303 \\
\hline he plague mouse . . . . . . . . . . . . . . . . . . & 305 \\
\hline 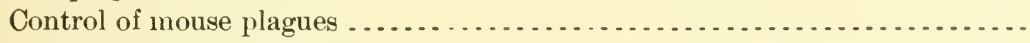 & 305 \\
\hline ntion of plagues ..... & 309 \\
\hline nclusion .............. & 309 \\
\hline
\end{tabular}

\section{ILLUSTRATIONS.}

Plate XXI. Lombardy poplar girdled by field mice................. 30

XXII. Alfalfa destroyed by field mice ........................ 304

XXIII. The Carson meadow mouse ......................... 304

XXIV. Fig. 1. Preparation and sacking of alfalfa hay for poisoning.Fig. 2. Gulls destroying field mice in the alfalfa fields of Humboldt Valley .....................................

XXV. Fig. 1. Brush drag used to obliterate mouse burrows.-Fig. 2. Effect of brush drag 



\title{
MOUSE PLAGUES, THEIR CONTROL AND PREVENTION.
}

\author{
By Stanley E. P'iper,
}

Assistant, Biological Survey.

\section{INTRODUCTION.}

Swarms of mice devastating the fields have been seen by very few American farmers, but such scourges are among the oldest and most disastrous known in history. Regarded with wonder and superstitious awe in early times, and still looked upon in some countries as miraculous, outbreaks of field mice are fraught with such dire consequences to agriculture as to have earned the name of plagues. In Europe and Asia mice have often almost completely destroyed crops over areas varying in extent from thousands of acres to whole provinces. Practically all vegetation suffers from their attacks. Pasturage, hay, alfalfa, clover, grain, whether growing or stacked, vineyards, shrubbery, and even forest trees hare been destroyed. As an example, Lenz thus describes a plague of mice in the years $1872-73$ :

In the rich corn lands of lower Saxony, Thuringia, and Hesse they [mice] abounded to a fearful extent. Half the harvest was destroyed-hundreds of thousands of acres were left untilled-and thousands of pounds were spent on their destruction. Agricultural societies and Governments were implored to seek ways and means of staying the plague.

The extraordinary and rapid increase of a species until its numbers assume the proportions of a plague is rare among mammals. Such increase is most frequent among the several species of short-tailed field mice and the lemmings. These animals, indeed, through their great fecundity, are liable to break out periodically in vast numbers. When they have increased excessively, some species migrate in large bodies, travel long distances, and devastate the regetation in their path. Other species, however, do not perform such marked migrations, but their excessive multiplication results in local and even more serious damage. Gregarious by nature, the vast bodies they form gradually extend from exhausted to fresh areas, until at length large districts have been overrun and laid waste.

A recent scourge in the United States lends more than usual interest to the subject, especially since the mice responsible are closely 
related to the species which have caused such widespread destruction in the Old World.

THE NEVADA OUTBREAK.

In 1907-8 an outbreak of field mice in Nevada, Utah, and northeast California threatened to develop into a plague as great as any recorded. The greatest loss occurred in the rich fields of alfalfa bordering Humboldt River for the last 10 or 12 miles of its course to the Sink (Humboldt Lake, Nevada). Noticeable here through gradually increasing damage during 1906, the field mice appeared early in the summer of 1907 in alarming numbers. By November they had overrun a large part of the cultivated area, and on many large ranches were estimated by one of the assistants of the Biological Survey to number from 8,000 to 12,000 to the acre. Fields were literally honeycombed by their holes, which numbered about 24,000 to the acre. During the summer they ruined one-third of the alfalfa, destroyed three-fourths of the potatoes and badly damaged the remainder, and severely injured root crops, as beets and carrots. Upon the disappearance of green food in fall they attacked the roots of alfalfa and trees, causing far more serious damage. They ate so large a percentage of the plants as to render many alfalfa fields a total loss. They girdled and killed most of the young shade trees planted along ditches and about the borders of fields. Even such hardy trees as large Lombardy and silver poplars were killed, while small orchards suffered severely. (Pl. XXI.) By January, 1908, the ravages had extended over considerably more of the district, and the main body of mice was gradually progressing to fresh fields. From this time, however, the abatement of the plague was rapid. By March 15 the invasion of fresh lands had ceased, though mice continued considerably in excess of normal abundance until May. By August they had practically disappeared from the valley. This scourge left a dismal scene of destruction over four-fifths of the cultivated area in the district. Of 20,000 acres in alfalfa, 15,000 were so completely destroyed as to require replanting. (Pl. XXII.) Considering the actual losses in crops and the cost of restoring the alfalfa fields, and allowing for the value of the wheat which replaced alfalfa in most of the ruined fields for the season of 1908, a conservative estimate of the losses in this district is $\$ 250,000$.

CONDITIONS FAVORING MOUSE PLAGUeS IN THE UNITED STATES.

While the Nevada plague is the most serious recorded in the United States, frequent milder outbreaks in many parts of the country indicate that practically all our species of short-tailed field 
mice periodically tend toward enormous multiplication. That this tendency is inherent can scarcely be doubted. Agricultural development, however, distinctly increases the danger of plagues by furthering the destruction of their natural enemies, by furnishing a great abundance of food, and by increasing the area in which they find favorable homes. The reclamation of arid lands affords most suitable conditions in large areas which were formerly uninhabitable. In these new lands, restricted by surrounding desert conditions, and stimulated by the rich food and dense shelter furnished by alfalfa, these mice are especially dangerous.

\section{NATURE AND DCRATION OF MOUSE PLAGUES.}

Accounts of mouse plagues agree that the mice increase in numbers for a season or two preceding serious outbreaks, that the final production of hordes is comparatively sudden, and that the period during which mice swarm over the land is rarely longer than a year. The total duration of a plague may thus cover three or four years. Natural control invariably asserts itself by somewhat sudden and decisive destruction of the abnormal numbers. Usually plagues subside during the winter and spring following their maximum, disease and predaceous enemies being the most apparent causes. The subsidence of a plague is usually followed by a long period of depression. It takes the mice several years to regain normal abundance, and several years more before the danger of producing a plague again 'becomes imminent; hence in no locality have plagues been recorded oftener than once in eight or ten years. Field mice are very prolific, and in the absence of natural checks might produce a plague every four or five years. From two to six litters of young are produced annually. The average number of young at a birth is about 6 , though frequently 8 to 10 are produced, and occasionally 12 or 13 . Even the young born early in the season are said to breed before fall.

These mice are always present in or near the districts which they occasionally overrun, but ordinarily live in small colonies in favorable locations, particularly in damp areas bordering swamps, streams, or irrigation ditches. In alfalfa and other cultivated lands where the food supply is abnormally plentiful, and particularly if the natural enemies of mice are destroyed, the animals may increase greatly in one or two seasons, and the first breeding in the second or third season may produce great numbers. Then the mice spread over a greater area, and as the food at hand is consumed they may move on in troops. The final production of hordes requires but a few months-in fact, a plague may be well established by fall. 
With the disappearance of green herbage in fall, reducing their food to roots and bark, mice move more rapidly from exhausted to fresh lands, and devastate larger areas. It is, then, through the progress of large bodies of mice, which may number thousands to the acre, that large districts are laid waste.

SUBSIDENCE OF PLAGUES.

After reaching a final autumnal climax and continuing through the winter in gradually lessening numbers, mouse plagues have usually abated early in the following spring, or at most have endured only through the ensuing summer. Like their development, the subsiding of such hosts is so gradual in the early stages as to be scarcely perceptible, though apparent enough a little later.

Most noticeable among the agencies which finally overcome them are predaceous birds and mammals. Attracted in large numbers to the feast, they live almost exclusively on mice during these periods, and, particularly in winter, make such severe inroads on the mice as to attract general attention. Still it is doubtful if, unassisted, they have ever overcome a plague. A conservative estimate places the number of predaceous birds which appeared in the stricken district in Humboldt Valley at 2,000; the predatory mammals at 1,000. It may be assumed that these 3,000 natural enemies would each destroy an average of 15 mice per day, or 450 per month, or collectively would kill 45,000 mice a day, or 1,350,000 per month. This number, vast as it is, is far too small to put an end to a well-established plague, although more than ample to check a plague during its early stages, or to completely wipe it out after the numbers have been materially reduced by poisons or other agencies.

In most of the accounts of mouse plagues the final destruction of the rodents has been ascribed to disease, and it is believed that the abatement of the plague in Humboldt Valley was aided by natural mortality. At intervals from January to March dead and dying mice were noticed in locations where poisoning could not have been the cause, but efforts to prove this mortality due to some specific bacterial disease failed.

In the spring the mice in this locality failed to reproduce, while the same species was breeding prolifically in other localities. In March several hundred females were examined in Humboldt Valley, of which very few were pregnant. Moreover, the mice themselves presented a different appearance from those seen when the plague was at its height-a fact noted by many ranchmen in the valley. During the fall of 1907 larger and much more vigorous individuals predominated, while in the spring of 1908 scarcely any of these remained. They continued in destructive numbers until the middle 


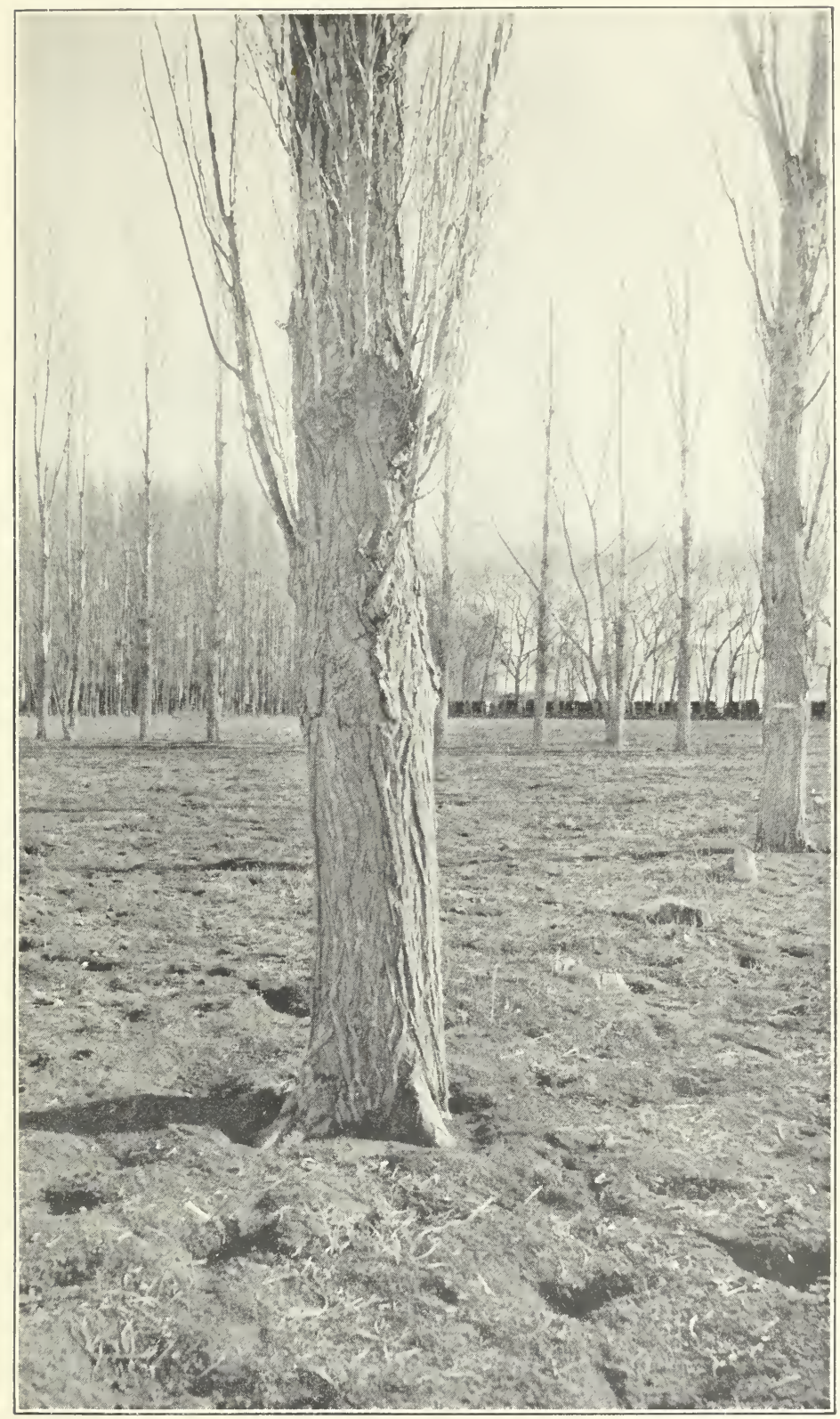

Lombardy Poplar Girdled about the Base by Field Mice. Mouse HOLES UNDER THE TREES. 



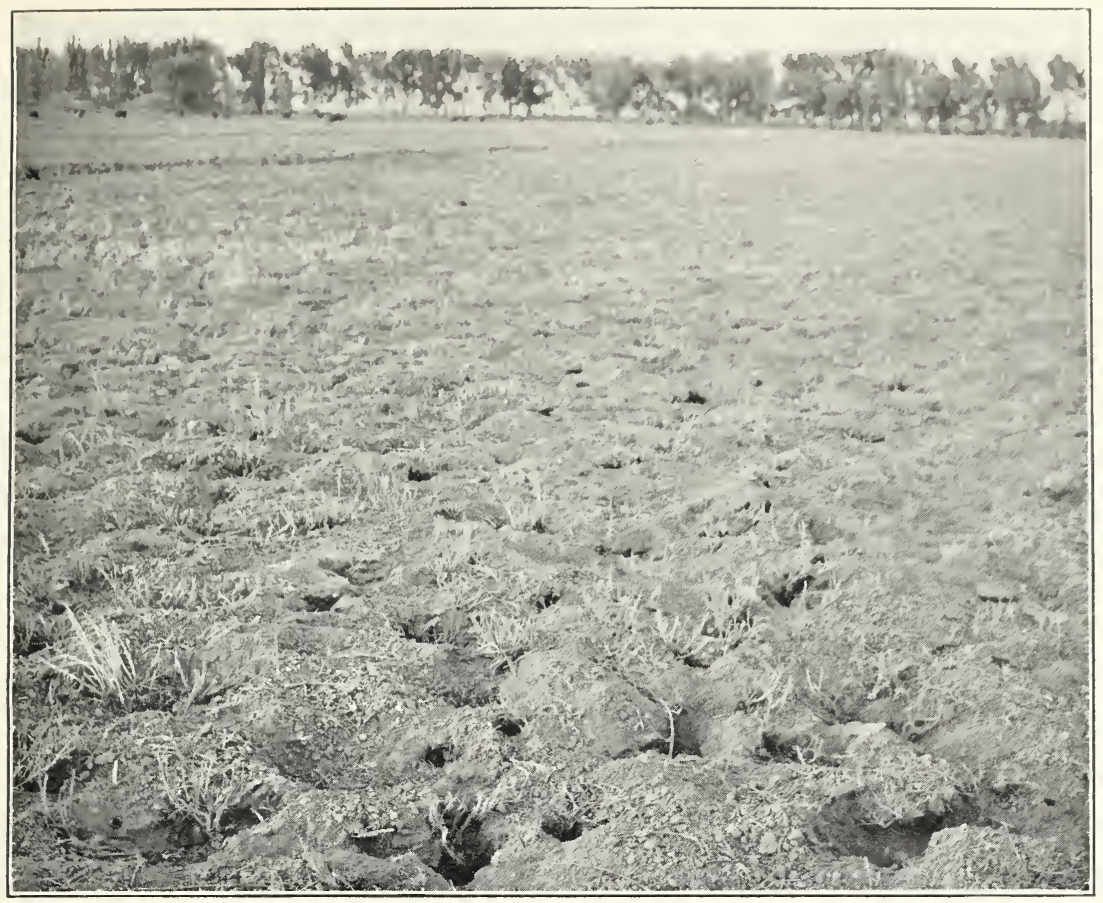

Fig. 1.-Alfalfa Field Destroyed by field Mice. General Condition of fields in Humboldt Valley, NeVada, in November, 1907.

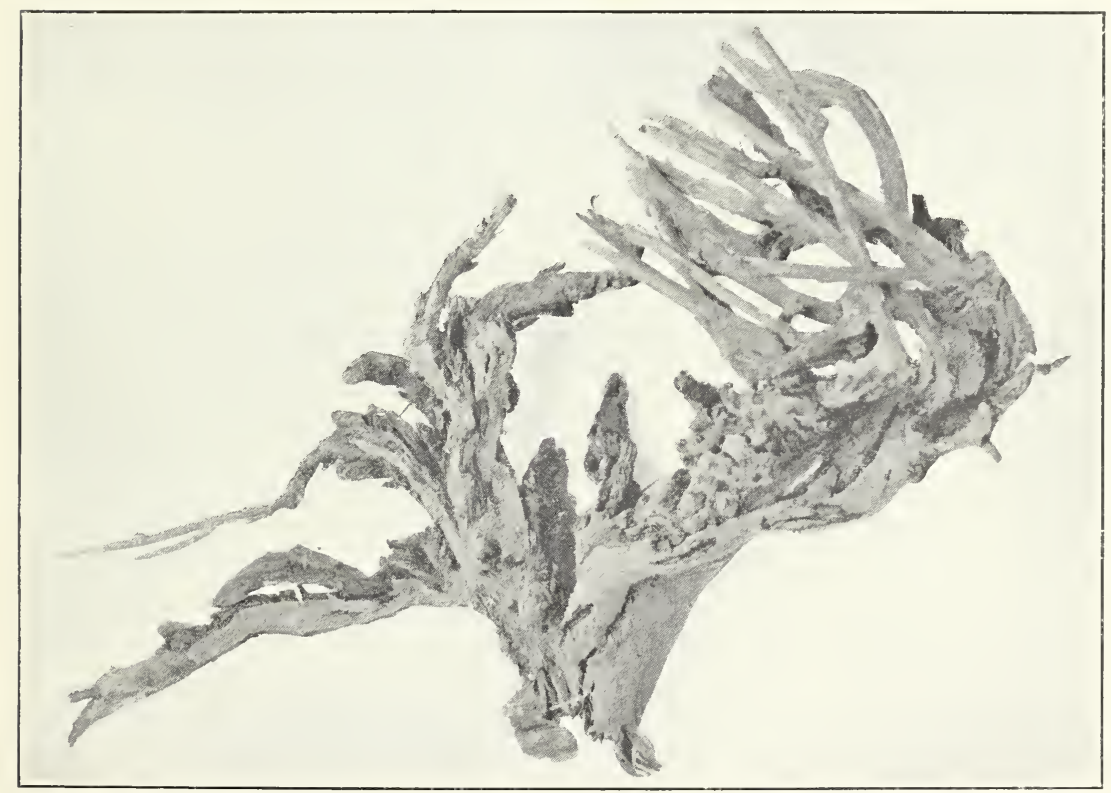

Fig. 2.- How Alfalfa Plants were destroyed. 



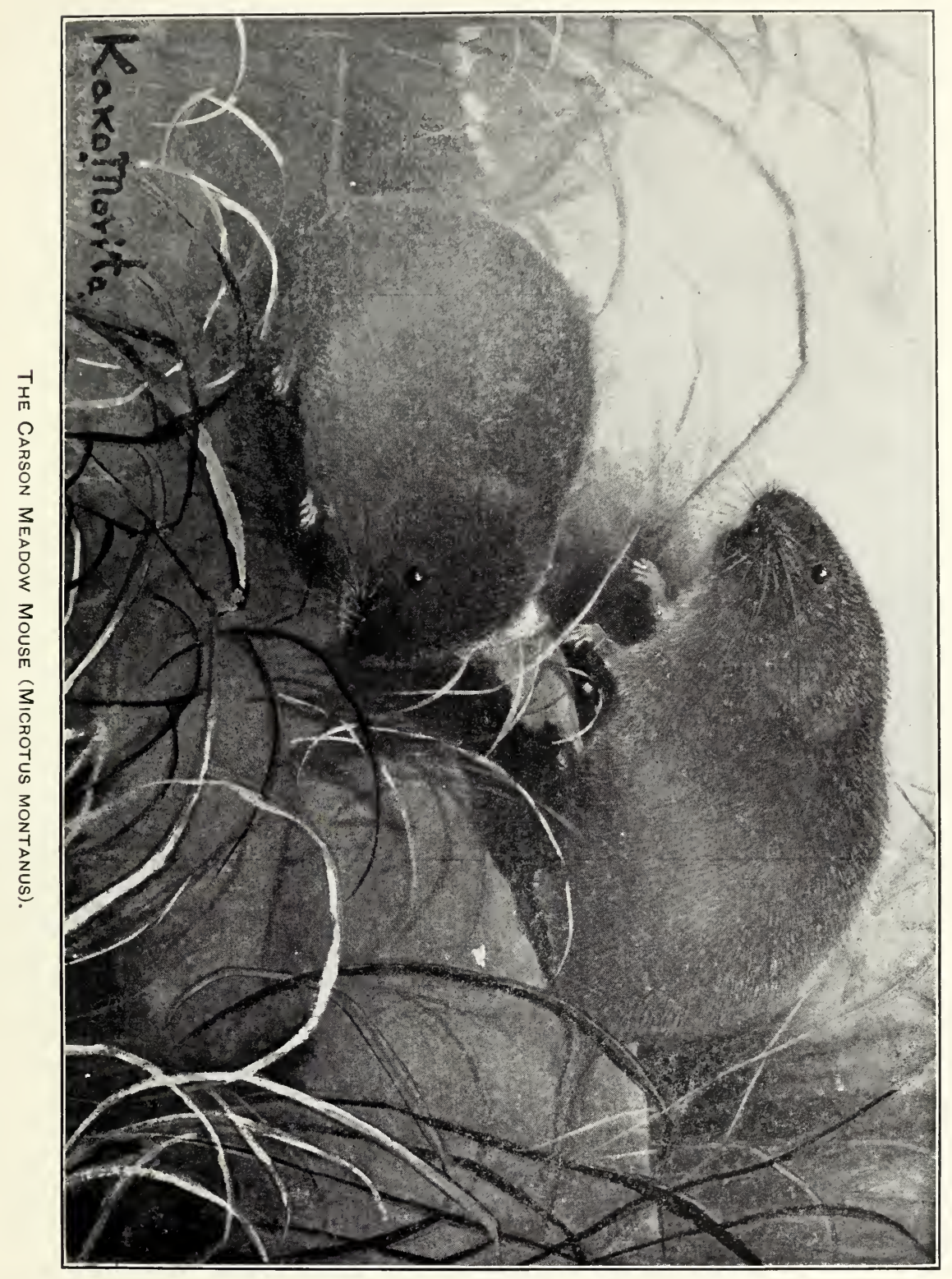



of March, 1908, and in more than usual abundance until May, and in some few centers eren later. But they did not noticeably breed with the return of favorable weather, and by August had practically disappeared.

THE I'LAGUE MOUSE.

The mice which produce plagues almost invariably belong to the genus Microtus, a group represented in the United States by about 50 species. Variously known in European countries as voles, wiihlmäuse, and campagnols, and in the United States as short-tailed field mice or meadow mice, their general characteristies are everywhere the same. Except in the deserts, one or more species are present in practically all parts of the country, and normally they are among the most abundant of mammals. The annual damage they cause to crops, nurseries, and orchards in the United States has been estimated at over $\$ 3,000,000$.

With few exceptions, the short-tailed field mice are readily distinguishable from other mice by their stout, chunky bodies, short legs, short, round tails, blunt muzzles, short ears, and rather small eyes. Most of them are dark brownish or grayish brown in color and considerably larger and heavier than the common house mouse. (Pl. XXIII.)

They live almost everywhere in damp meadows, where their presence may be detected among the grass and weeds by small, welldefined, crooked trails, along which at intervals are little heaps of fresh grass or other herbage. In alfalfa or clover fields their numerous small burrows are usually in colonies. As a rule they appear first along ditches or about damp areas, where dead plants are almost certain evidence of their work.

\section{CONTROL OF MOUSE PLAGUES.}

In the past many methods of destroying field mice have been tried, yet the records describe no instance in which well-established plagues have been successfully suppressed. Failing to recognize the early stage of the plague, the people in stricken districts have usually not adopted vigorous measures until after the fields were swarming with mice. The failure, then, has been due partly to lack of cooperation and partly to lack of knowledge of quick, cheap, and effective measures. Without witnessing such a plague one can hardly form a conception of the almost incredible numbers of mice and of the magnitude of the task of destroying them.

Among methods of little value which have been tried in other countries to rid the land of these scourges are rolling the land with 
heavy cylinders; trampling it by cavalry or by droves of sheep; liberating large numbers of cats; and injecting water, steam, or suffocating gases into the mouse burrows. Many measures practicable on a small scale or of value in the early stages are entirely inadequate for the suppression of well-established plagues, particularly where farms are as large as in the United States. Among such methods are digging trenches or pitfalls wider at the bottom than at the top, into which the mice fall; killing by means of traps, clubs, or dogs; burning off the herbage in infested areas; and flooding the fields. The elimination of these leaves as methods generally applicable for suppressing plagues only two-the employment of disease and poisoning.

DISEASE.

The employment of bacterial diseases fatal to rodents has been a subject of considerable research and experimentation. It is evident that a disease which will quickly spread from one mouse to another, without endangering other animals, is exceedingly desirable. While epidemics of disease have been frequently considered a prime cause of the abatement of plagues, it has not yet been demonstrated that such epidemics can be artificially produced. Dr. Loeffler's experiments in destroying field mice in Thessaly in 1892-93 by means of the Bacillus typhimurium were reported as completely successful, but now it appears questionable whether these results did more than synchronize with the natural abatement of the plague. Experiments in Russia in 1894 with the similar organism isolated by Mereschkovski were also reported as successful; and in France, in 1904, the Danysz virus is said to have proved in a measure efficacious.

Attempts by ranchmen to produce epidemic disease among the mice in Humboldt Valley by means of advertised bacterial preparations failed. Although we admit that, when properly distributed and fresh, these organisms are fatal to those mice which eat them, yet on this basis they are still far too expensive for general employment.

POISONING.

Poisoning is the most generally applicable, cheapest, and most certain means for controlling mouse plagues at present known. Poison preparations, however, must possess, in addition to effectiveness, the least possible danger to man, to domestic stock, and to valuable wild birds and mammals. The following recommendations are based on extensive experiments and practice during the mouse plague in Nevada, and are applicable to similar species of mice elsewhere. Phosphorus, on account of its extremely dangerous character, the limited number of baits on which it can be used, and its destructive- 
ness to birds and mammals, is out of the question. Among less virulent mineral poisons, arsenic, barium carbonate, lead acetate, and mercuric chlorid give no results warranting their recommendation; moreover, when used on a large scale, they prove quite as expensive as strychnine.

All things considered, strychnia sulphate is by far the best poison to employ. Properly used, this drug at 75 cents to $\$ 1$ an ounce is cheaper for the purpose than arsenic at 15 cents a pound. Used on grain it is considerably more expensive than phosphorus, but it can be used on other mediums which make it the cheapest poison available. Tests with a variety of materials show that three possess great advantages as vehicles for poison. These are alfalfa hay, green alfalfa, and crushed wheat. They should be prepared as follows:

Poisoned alfalfa hay.-Chop 30 pounds of good, fresh alfalfa hay into about 2 -inch lengths with a feed cutter. Then place the hay in a large metal receptacle and sprinkle with 3 gallons of fresh water. Thoroughly dissolve 1 ounce of strychnia sulphate in 2 gallons of water by heating in a closed vessel; sprinkle over the dampened hay and mix well. (Pl. XXIV, fig. 1.)

Poisoned green alfalfa.-Heat 1 ounce of strychnia sulphate in half a gallon of water until thoroughly dissolved, add to 1 gallon of cold water, and sprinkle this solution slowly over 45 pounds of fresh green alfalfa, cut into lengths of 2 or 3 inches. Mix until the free solution is taken up.

Poisoned Crushed wheat.-Dissolve 1 ounce of strychnia sulphate in 2 gallons of water by heating. Sprinkle the solution over 60 pounds of rolled or crushed wheat in a metal receptacle and mix well. If the preparation is to be kept for several days, 2 tablespoonfuls of powdered borax may be added to prevent fermentation.

Poisoned alfalfa hay proved the best during winter, when green food was absent, and was recommended generally in Humboldt Valley. From January 15 to March 15 it was used extensively in destroying the mice in the area in which they were most abundant, and its use was not attended by a single accident to birds or to animals. From 7 to 15 men were employed on a single ranch in distributing it, placing a small pinch, equal to about a teaspoonful, at the mouth of each burrow, or in cold, rough weather dropping it into the underground runs. In fields where mouse holes numbered 10,000 to 24,000 to the acre, there were 10 or more burrows for each mouse, and in fields partially deserted the proportion of unoccupied holes was much greater. Dragging the fields with a brush drag (Pl. XXV) to obliterate the holes proved important, for within twenty-four hours the occupied holes were reopened, and poisoning 
could be done with a saving of nearly 50 per cent in labor and materials. A single treatment of the land with poisoned alfalfa hay destroyed 85 to 95 per cent of the mice at a cost, including labor, of about 35 cents an acre. Had this method been employed earlier, it is certain that the plague could have been broken and a great part of the ravages averted.

In April, 1908, mice had become so alarmingly abundant in parts of Carson Valley, Nevada, that an urgent appeal for assistance was sent to the Biological Survey. On risiting the valley it was found that in an area of about 2,000 acres near Minden the mice numbered 500 to 1,000 to each acre and had already destroyed 10 to 25 per cent of the alfalfa, and that by reason of rapid reproduction they gave every indication of producing a plague similar to that which had stricken Humboldt Valley. Preliminary tests of a number of poisoned baits were at once carried out. Poisoned green alfalfa placed in the trails and in the burrows of the mice proved fatal to practically all the mice in the areas treated-not a remarkable result, as these mice habitually cut green alfalfa, stack it along their runs, and later carry it into their holes. Poisoned crushed wheat proved distinctly better than the whole grain, killing a larger number of the mice, particularly of the small young.

The importance of treating quickly the infested area prevented the extensive use of green alfalfa, since this material must be distributed during evening hour's to prevent drying by the sun, while crushed wheat may be distributed all day long. Poisoning with crushed wheat resulted in the destruction of fully 85 per cent of the mice, at an average cost, including labor, of about 40 cents an acre. Unfortunately a large number of magpies and blackbirds fell victims to the poisoned grain; while to a less extent meadowlarks, killdees, and mourning doves were killed. Under conditions threatening a plague the destruction of the mice is of prime importance. but care in putting out the smallest amount of poison needed to destroy the mice will greatly lessen the danger to birds. A teaspoonful of properly poisoned grain is sufficient to treat three or four mouse holes.

Poisoned green alfalfa should be used where it is possible in-preference to crushed wheat, since it is even more effective and eliminates all danger to birds. It is particularly recommended for small areas or where mice are not extremely abundant. Irrigation drives the mice temporarily to the elevated ditch embankments and to the borders of fields, thus presenting an opportunity to use this material with great effect. 


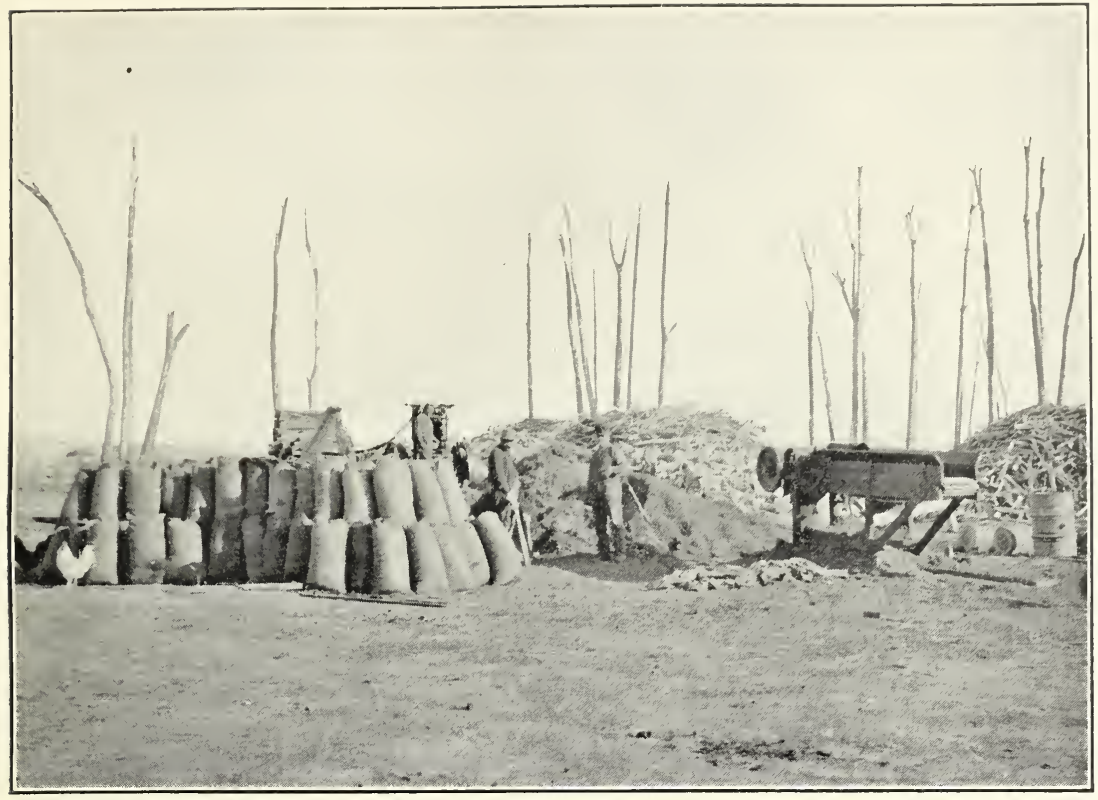

Fig. 1.-Preparation and Sacking of Alfalfa hay, indicating the Extent to Which it Was Used in PoIsoning Operations in Humboldt Valley, Nevada.

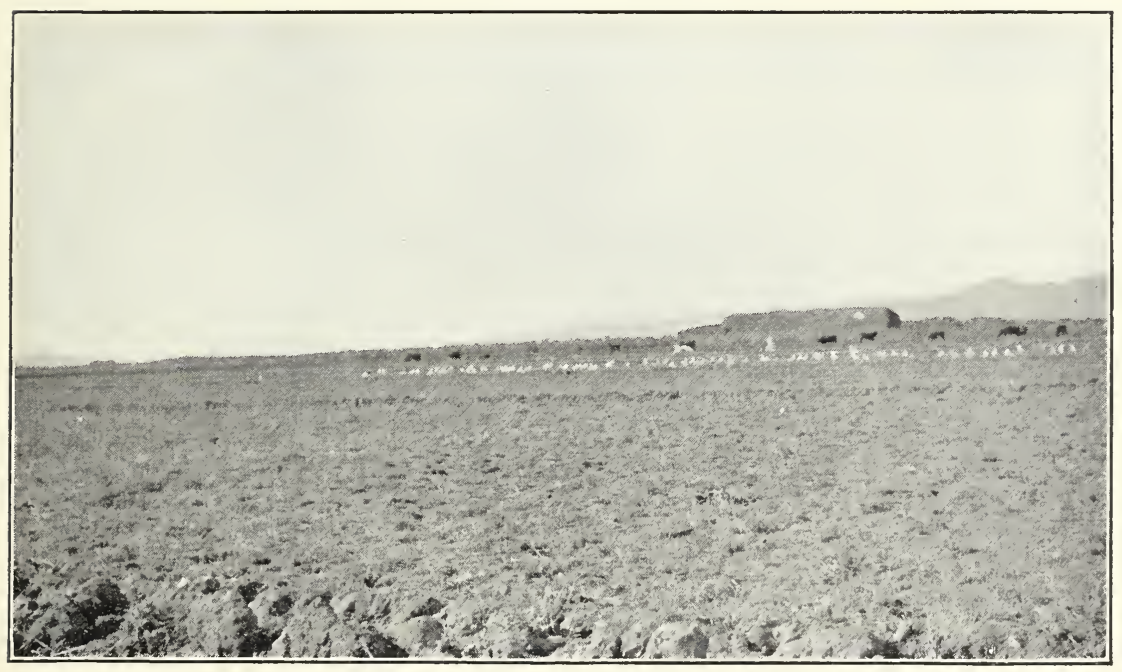

Fig. 2.-Gulls Destroying Field Mice in the Alfalfa fields of humboldt Valley. 



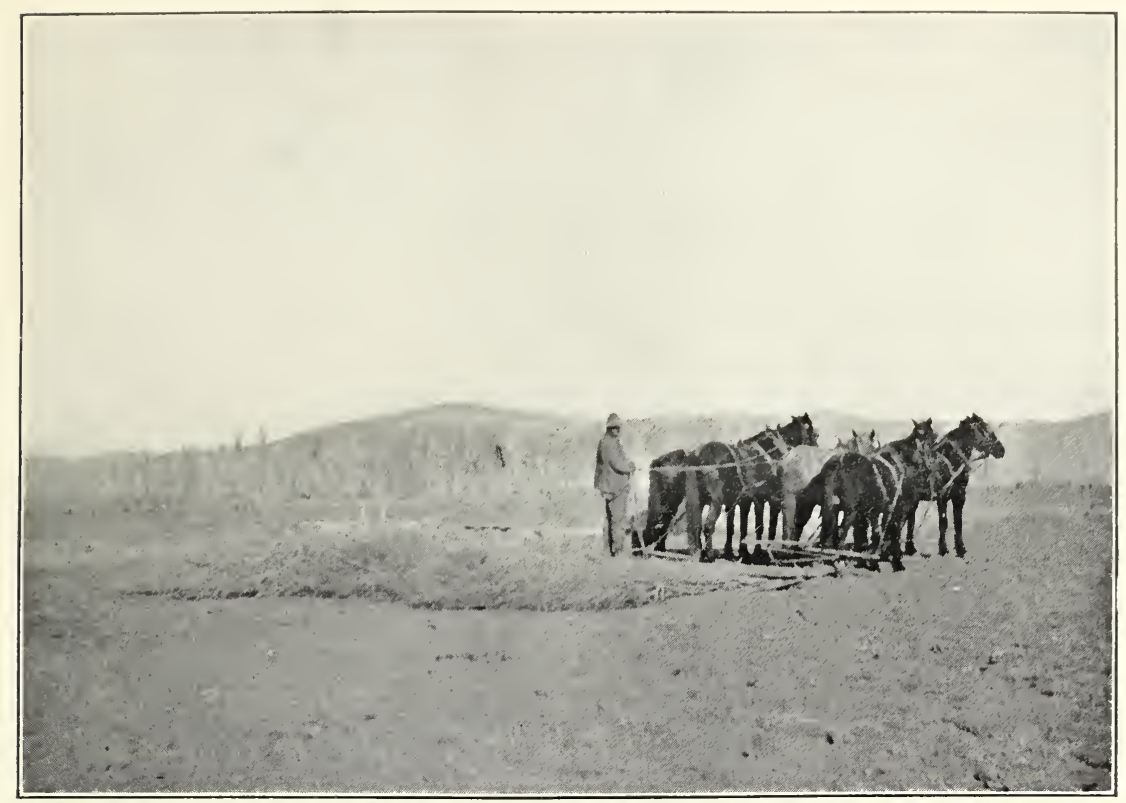

Fig. 1.-Brush Drag Used to Obliterate mouse Burrows.

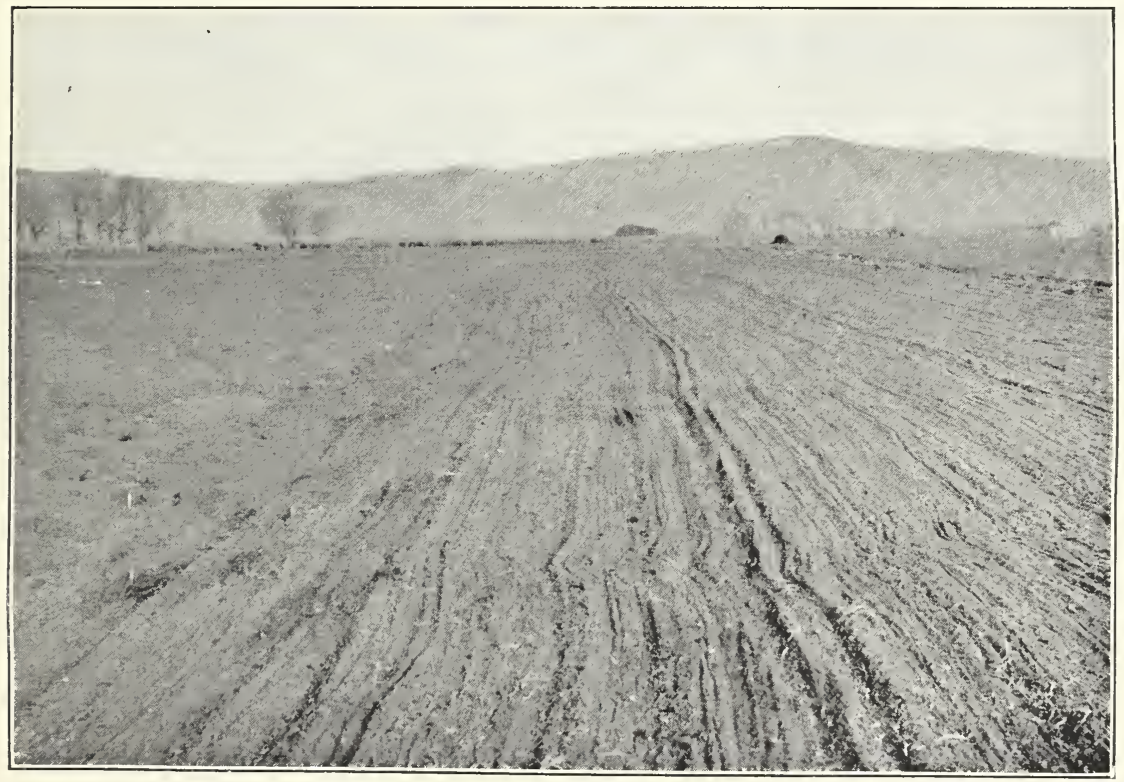

Fig. 2.-EFFECT OF BRUSH DRAG. 

The prevention of plagues is comparatively easy. Their gradual development affords opportunities to suppress them, even after the damage has become quite extensive. The destruction of the mice whenever they become al all numerous not only prevents considerable damage, but is the best safeguard against serious outbreaks. Systematic poisoning must be relied upon to repress them when they are obviously on the increase, but there are many inexpensive methods for preventing this increase. The destruction of rank grasses and weeds along fences and ditches, and particularly the pasturing off of the last growth of alfalfa in fall, thus exposing the mice to the attack of predaceous enemies, are important. Winter burning the dry vegetation on wild hay lands, on strips bordering fields, and on swampy or otherwise waste areas in and about cultivated fields will aid materially in controlling them. The survivors may invade cultivated fields, but there they can be more readily poisoned. Flooding the fields in cold winter weather, when the mice quickly perish from exposure, is an effective method in irrigated lands. Plows turn out the burrows and nests of practically all the mice present and render them easy victims for dogs, which when trained to kill mice can not be too highly recommended as effective and inexpensive aids in controlling the pests.

Among the agencies which check the increase of field mice none are more important than their predaceous enemies. These mice, the favorite food of many birds and mammals, active night and day, summer and winter, are preyed upon more than any other mammal. That hawks, owls, gulls, crows, ravens, and herons among birds and skunks, weasels, foxes, and badgers among mammals are persistent enemies of field mice and other rodent pests has been often pointed out. The protection and encouragement of these valuable allies of the farmer can not be too strongly advocated.

(Pl. XXIV, fig. 2.)

\section{CONCLUSION.}

Mouse plagues are usually preceded for a season or more by noticeable damage to crops, and success in checking them depends upon prompt recognition of the early stages of outbreaks. When mice first attract attention by increased numbers and by damage here and there, it is high time to destroy them.

The work carried on by the Biological Survey in Nevada, especially in Carson Valley, demonstrated that plagues can be controlled. The systematic poisoning of 10,000 acres in Humboldt Valley during the fall months, at a cost of about $\$+, 000$, would have prevented the larger part of the damage, and it is safe to say would have saved at least $\$ 175,000$ worth of alfalfa. 
But prevention of mouse plagues is far better and easier than their control after they have gained full headway. Field mice, wherever they abound, should be regarded as a menace, and their natural enemies should be protected and encouraged. In ordinary times mice should be killed by dogs, by flooding fields in cold weather, by winter poisoning, and by burning herbage which affords them shelter. Holding field mice in check is worth its cost many times over in minimizing the steady drain they inflict on farm products; moreover, it is the best preventive of widespread devastation. 

